\title{
Feeding Behavior, Abdominal Fat and Laying Performance in Laying Hens Given Diets Containing Red Pepper
}

\author{
Mitsuhiro Furuse ${ }^{1)}$, Shin-ichi NaKajima ${ }^{2)}$, Syuichi Miyagawa ${ }^{2)}$, \\ Jiro NAKAGAWA ${ }^{2)}$ and Jun-ichi OKUMURA ${ }^{1)}$ \\ ${ }^{1)}$ Laboratory of Animal Nutrition, School of Agriculture, \\ Nagoya University, Nagoya 464-01 \\ ${ }^{2)}$ Toyohashi Feed Mills Co., Ltd., Toyohashi 440
}

\begin{abstract}
Capsaicin (CAP), a pungent principle of hot pepper, enhanced the energy metabolism of rats through the beta-adrenergic action of CAP itself. The present study was done to clarify the effects of dietary red pepper on feeding behavior, abdominal fat content and laying performance in laying hens. Single Comb White Leghorn laying hens were given diets containing varying levels of red pepper $(0,2$ and $10 \mathrm{~g} / \mathrm{kg}$ diet $)$ ad libitum for 10 weeks. The red pepper contains $0.22 \%$ CAP. There were no significant differences in feeding behavior in any treatments. This suggests that the receptor for the pungent stimuli might be deficient in chickens. The abdominal fat content and liver color were not altered by dietary red pepper, being implied that the beta-adrenergic action of CAP might be smaller in chickens than in mammals. Laying performances were hardly influenced by dietary red pepper. Roche color fan score and the redness of egg yolk color significantly increased as the dietary red pepper content increased, but the reverse was true for the yellowness and lightness of egg yolk color.

In conclusion, it is difficult to depress the excess fat deposition of laying hens by dietary red pepper through the action of CAP. Dietary red pepper is only available for the egg yolk pigmentation, particularly in redness.
\end{abstract}

(Jpn. Poult. Sci., 31 : 45-52, 1994)

Key words : red pepper, capsaicin, laying hens, abdominal fat, egg yolk color, capsanthin

\section{Introduction}

Excess adipose tissue represents a useless energy deposit in the body, and the control of fat deposition is a big concern in modern strains of meat- and laying-type chickens. Higher dietary energy concentration tends to result in an increased energy intake and greater abdominal fat deposition. The liver of laying hens exhibits greater lipid synthesis compared with that of broilers, because it synthesizes triglyceride and secretes very low density lipoproteins (VLDL) in amounts sufficient to meet a high egg production rate. However, the control of the synthesis and secretion of triglyceride and VLDL in the liver could be disturbed by the incidence of fatty liver or fatty liver hemorrhagic syndrome (Wolford and Polin, 1972 ; Pearson and Butler, 1978). Force molting is successfully used to induce a pause in the laying cycle, which results in higher egg production including of improved shell strength and interior egg quality in the later stage. These improvements in laying performances would be explained by rerduced fat in liver and uterus, because most molting regimens have been initiated by fasting. 
Capsaicin (CAP, 8-methyl- $N$-vanilly-6-nonenamide) is the active substance responsible for the irritating and pungent effects of various species of hot pepper. CAP has emerged as a relatively selective neurotoxin for small-diameter sensory neurons (JANCSO et al., 1977 ; JESSELl et al., 1978 ; NAGY et al., 1981), many of which contain neuroactive peptides such as substance $\mathrm{P}$, cholecystokinin and somatostatin. On the other hand, CAP enhanced the energy metabolism of rats through the beta-adrenergic action of CAP itself (KAWADA et al., $1986 \mathrm{~b}$ ) and decreased perirenal adipose tissuse weight (KAWADA et al., $1986 \mathrm{a}$ ).

The present study was conducted to clarify whether or not dietary red pepper 1) decreases abdominal fat content, 2) alters feeding behavior, and 3) influences laying performances in laying hens in the later stage.

\section{Meterials and Methods}

Single Comb White Leghorn laying hens (Decalb-TX 35, 480 day-old) given a commercial diet (Scott ${ }^{\circledR} ; \mathrm{CP} 17 \%$ and ME $11.9 \mathrm{~kJ} / \mathrm{g}$, Toyohashi Feed Mills, Col. Ltd., Toyohashi) were allocated to three groups (12 birds/diet), so that mean body weight, egg specific gravity and egg production rate were as uniform as possible. They were housed individually in wire-mesh cages in a constant-temperature windowless poultry house $\left(20^{\circ} \mathrm{C}\right)$ with a $16 \mathrm{~L}: 8 \mathrm{D}$ light cycle.

Table 1 shows the composition of a control diet. Red pepper was supplemented to the control diet at levels of 2 and $10 \mathrm{~g} / \mathrm{kg}$ diet at the expense of cellulose. The red pepper used here contains $220 \mathrm{mg}$ CAP and $59 \mathrm{mg}$ xanthophylls $/ 100 \mathrm{~g}$ diet, respectively. The amount of capsanthin, red pigment, in the red pepper was $43 \mathrm{mg} / 100 \mathrm{~g}$. The birds were given the experimental diets and water ad libitum for 10 weeks. Food consumption was measured daily during first week and thereafter weekly. The egg shell strength was measured with the specific strength measuring apparatus (Fujihira Industry Co. Ltd., Tokyo). The egg shell strength and egg specific gravity were measured daliy during first week and thereafter weekly. The egg yolk color was measured for $\mathrm{L}^{*}, \mathrm{a}^{*}$ and $\mathrm{b}^{*}$ color using a chroma meter (CR-200, Minolta Camera Co. Ltd., Osaka) during 3 to 10 weeks of experiment. The $\mathrm{L}^{*}$ color shows the lightness, and the value for $\mathrm{a}^{*}$ color indicates color in redness and the $\mathrm{b}^{*}$ color presents yellowness. The egg yolk color was also determined by the Roche color fan during 5 to 10 weeks of experiment. On the final experimental day, birds were killed by decapitation. Both abdominal fat and fat surrounding the gizzard and proventriculus were removed and weighed. Liver color was measured by the chroma meter.

Analysis of variance was used to analyze the data, and for comparison of the individual treatment differences, Duncan's multiple range test (Duncan, 1955) was applied. Regression equation was fitted to the Roche color fan score. Statistical proccdures were done using a commercially available statistical package (SAS, 1985).

\section{Results}

Two birds of $1.0 \%$ CAP group molted during the experiment, so these two values were deleted from the calculation. 
Influences of dietary red pepper on daily food intake of laying hens during first week and on daily food intake during each week are indicated in Fig. 1A and Fig. 1B. No significant dietary effects were observed in a short and long term feeding behavior of laying hens.

Relative weight of liver and abdominal fat, and liver color are shown in Table 2. Neither values were influenced by dietary treatments.

As shown in Fig. 2, dietary red pepper did not influence the egg production rate on hen day basis. Although no significant difference was detected, overall mean of egg production rate in the $1 \%$ red pepper group $(88.3 \pm 2.0 \%)$ during the experimental period was about $3 \%$ higher than the control group $(85.5 \pm 1.5 \%)$. Overall means of egg weight, shell strength and specific gravity were not also improved by dietary red pepper (Table 3).

The values for egg yolk color are given in Fig. 3A-D. Roche color fan score and the redness of yolk color were enhanced as the dietary red pepper increased and the

Table 1. Composition of a control diet

\begin{tabular}{|c|c|}
\hline Ingredients & $(\%)$ \\
\hline Ground yellow corn & 42.97 \\
\hline Milo & 17.82 \\
\hline Soybean meal & 8.22 \\
\hline Corn gluten meal & 7.72 \\
\hline Corn germ meal & 3.47 \\
\hline Corn germ cake & 2.97 \\
\hline Rapeseed meal & 2.97 \\
\hline Fish meal & 2.48 \\
\hline Feather meal & 2.08 \\
\hline Meat and bone meal & 1.98 \\
\hline Fish soluble & 1.49 \\
\hline Rice bran & 1.49 \\
\hline Corn gluten feed & 1.49 \\
\hline Tallow & 0.99 \\
\hline Tricalcium phosphate & 0.50 \\
\hline Calcium carbonate & 0.20 \\
\hline Vitamin and mineral mixture ${ }^{1}$ & 0.08 \\
\hline DL-Methionine & 0.05 \\
\hline Biored & 0.02 \\
\hline Sodium chloride & 0.01 \\
\hline Cellulose & 1.00 \\
\hline Crude protein & 17.0 \\
\hline $\mathrm{ME}(\mathrm{kJ} / \mathrm{g})$ & 11.9 \\
\hline
\end{tabular}

1 Provided following per $\mathrm{kg}$ of diet: retinol, 4,000 IU; cholecalciferol, $1,600 \mathrm{IU}$; DL- $\boldsymbol{\alpha}$-tocopherol, $3 \mathrm{mg}$; menadione, $4 \mathrm{mg}$; riboflavin, $3 \mathrm{mg}$; cyanocobalamin, 2 $\mu \mathrm{g}$; niacin, $10 \mathrm{mg}$; pantothenic acid, $2 \mathrm{mg}$; folic acid, 0.5 $\mathrm{mg}$; choline chloride, $81 \mathrm{mg} ; \mathrm{MnCO}_{3}, \quad 84 \mathrm{mg} ; \mathrm{ZnCO}_{3}, \quad 77$ $\mathrm{mg} ; \mathrm{CuSO}_{4}, 13 \mathrm{mg}$; and $\mathrm{Ca}\left(\mathrm{IO}_{3}\right)_{2}, 0.5 \mathrm{mg}$. 


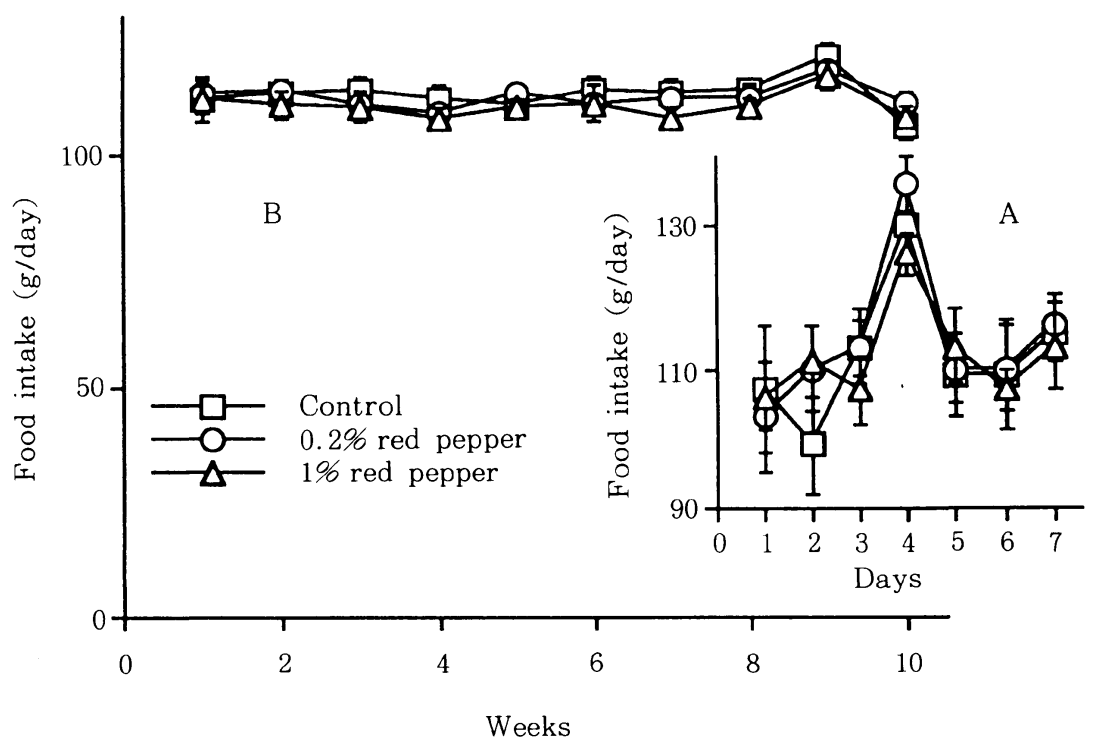

Fig. 1. Influence of dietary red pepper on daily food intake during first week (A) and on daily food intake during each week (B) of laying hens. Values are means \pm SEM for 12 (0 and $0.2 \%$ groups) and 10 birds (1.0\% group).

Table 2. Effect of dietary red pepper for 10 weeks on liver and abdominal fat weight, and liver color of laying hens

\begin{tabular}{|c|c|c|c|c|c|c|}
\hline \multirow{2}{*}{$\begin{array}{l}\text { Red pepper } \\
\text { (\% diet) }\end{array}$} & \multirow{2}{*}{$\begin{array}{l}\text { Body weight } \\
(\mathrm{kg})\end{array}$} & \multicolumn{2}{|c|}{ Relative weight $(\mathrm{g} / \mathrm{kg})$} & \multicolumn{3}{|c|}{ Liver color ${ }^{1}$} \\
\hline & & Liver & $\underset{\text { fat }}{\text { Abdominal }}$ & $\mathrm{L}^{*}$ color & $\mathrm{a}^{*}$ color & $\mathrm{b}^{*}$ color \\
\hline 0 & $1.74 \pm 0.05$ & $24 \pm 1$ & $33 \pm 4$ & $45 \pm 1$ & $12 \pm 0$ & $23 \pm 1$ \\
\hline 0.2 & $1.74 \pm 0.06$ & $23 \pm 1$ & $33 \pm 4$ & $44 \pm 2$ & $12 \pm 0$ & $23 \pm 2$ \\
\hline 1.0 & $1.67 \pm 0.06$ & $24 \pm 1$ & $30 \pm 5$ & $44 \pm 1$ & $13 \pm 0$ & $23 \pm 1$ \\
\hline
\end{tabular}

Values are means $\pm \mathrm{SEM}$ for 12 ( 0 and $0.2 \%$ groups) and 10 birds ( $1.0 \pm$ group).

${ }^{1}$ Liver color shows : $\mathrm{L}^{*}$ color, lightness ; $\mathrm{a}^{*}$ color, redness ; $\mathrm{b}^{*}$ color, yellowness. Units were CIE (Commission International de l'Eclairage) standard.

reverse was true for the yellowness and lightness. All parameters $(\mathrm{Y})$ were linearly correlated with dietary red pepper levels $(\mathrm{X}, \%)$, and the regression equations were :

Roche color fan score : $\mathrm{Y}=9.19+3.37 \mathrm{X}\left(\mathrm{R}^{2}=0.954, \mathrm{P}<0.0001\right)$,

redness of yolk color : $\mathrm{Y}=0.19+5.93 \mathrm{X}\left(\mathrm{R}^{2}=0.990, \mathrm{P}<0.0001\right)$,

yellowness of yolk color : $\mathrm{Y}=40.8-2.89 \mathrm{X}\left(\mathrm{R}^{2}=0.726, \mathrm{P}<0.0001\right)$,

and lightness of yolk color : $\mathrm{Y}=55.3-3.19 \mathrm{X}\left(\mathrm{R}^{2}=0.705, \mathrm{P}<0.0001\right)$

\section{Discussion}

CAP, when administered orally, parenterally or intracerebrally, may produce a fall in body temperature in a wide variety of animals including mice, rats, guinea pigs, rabbits, cats, dogs, goats and hibernators (HoRI, 1984). According to KAWADA et al. (1986 


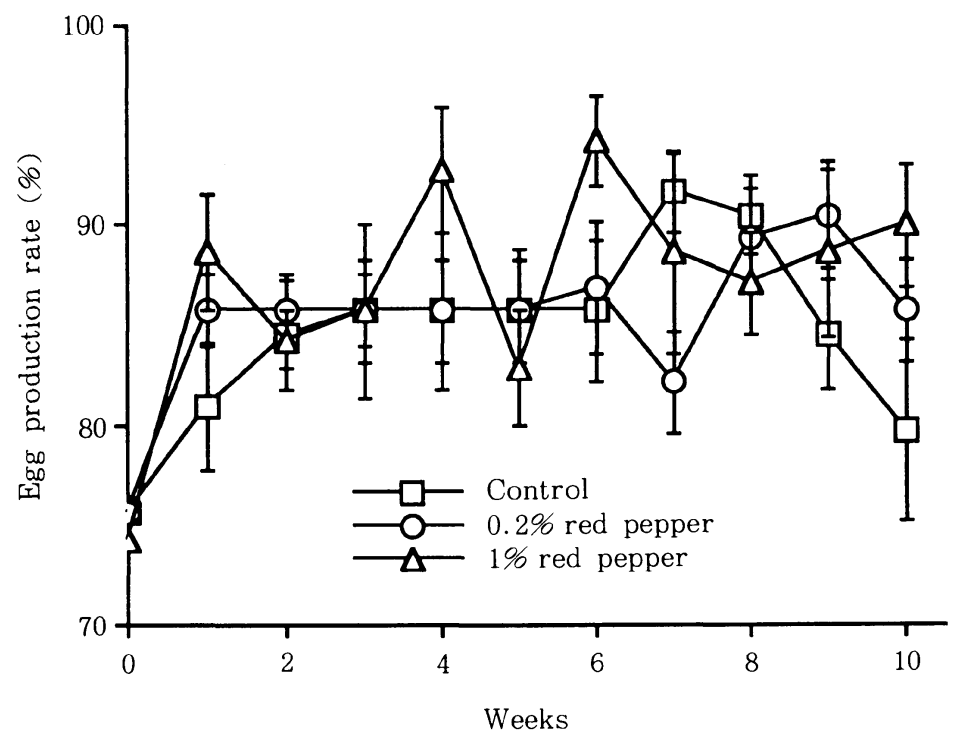

Fig. 2. Influence of dietary red pepper on the egg production rate on hen day basis. Values are means \pm SEM for 12 ( 0 and $0.2 \%$ groups) and 10 birds ( $1.0 \%$ group).

Table 3. Effect of dietary red pepper on egg weight, egg shell strength and egg specific gravity of laying hen (overall means during the experimental period)

\begin{tabular}{cccc}
\hline $\begin{array}{c}\text { Red pepper } \\
(\% \text { diet })\end{array}$ & $\begin{array}{c}\text { Egg weight } \\
(\mathrm{g})\end{array}$ & $\begin{array}{c}\text { Egg shell strength } \\
\text { (arbitrary unit) }\end{array}$ & $\begin{array}{c}\text { Egg specific } \\
\text { gravity }\end{array}$ \\
\hline 0 & $66.9 \pm 1.3$ & $2.94 \pm 0.1$ & $1.08 \pm 0.00$ \\
0.2 & $67.8 \pm 1.6$ & $3.17 \pm 0.1$ & $1.08 \pm 0.00$ \\
1.0 & $64.5 \pm 0.6$ & $2.96 \pm 0.1$ & $1.08 \pm 0.00$ \\
\hline
\end{tabular}

Values are means \pm SEM for 12 ( 0 and $0.2 \%$ groups) and 10 birds ( $1.0 \%$ group).

a), the serum triglyceride concentration and perirenal adipose tissue weight were lower when CAP was present in the diet. These results could be explained by the beta-adrenergic action of CAP (KAWADA et al., 1986 b). To our knowledge, however, there is no information on the effect of dietary CAP on lipid metabolism of laying hens. We used a red pepper, but not CAP itself, to consider a practical use in the diet. In the present study, dietary red pepper did not decrease the abdominal fat weight. The liver color was also applied as an index of fat content of the liver; the higher the yellowness and lightness, the higher the liver lipid content (FURUSE et al., 1990), though no significant changes were observed by dietary treatments. These results might be true, because cimaterol, one of the beta-adrenergic agonist, did not reduce the size of the abdominal fat pad of broiler chickens in spite of significant reductions in the amount of fat in the carcass (DALRYMPLE and INGLE, 1987). Furthermore, the effect of administration of clenbuterol, a beta-adrenergic agonist, on the liver fat was negligible in female broiler (Muramatsu et al., 1991).

We have speculated that a large amount of red pepper could reduce the food intake of laying hens, because CAP has an irritating and pungent effect. However, feeding behavior was hardly changed in both short and long term even though diets contained 

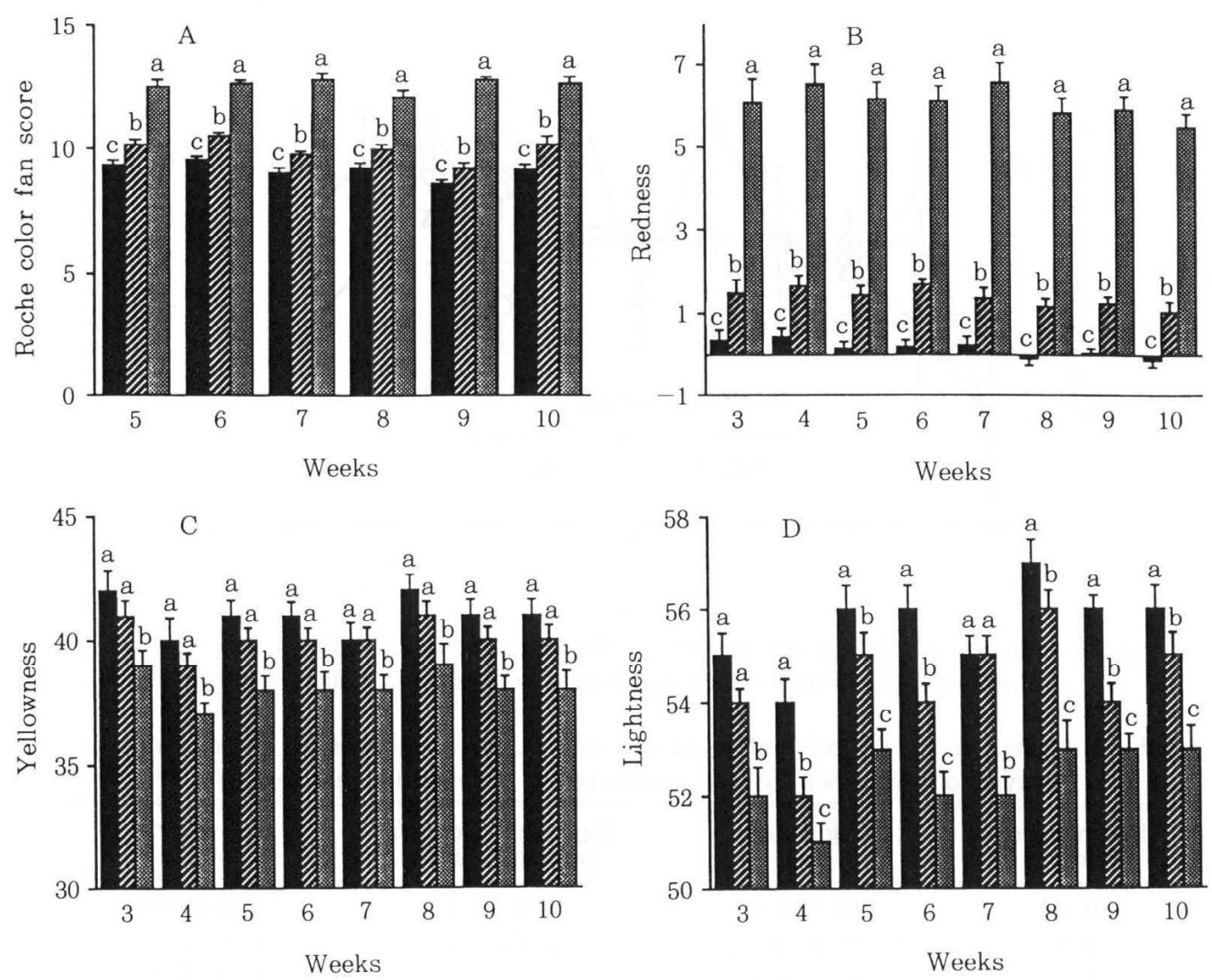

Fig. 3. Influence of dietary red pepper on Roche color fan score (A), and redness (B), yellowness (C) and lightness (D) of egg yolk color. The left column is the control group : the center is $0.2 \%$ red pepper group : and the right is $1 \%$ red pepper group. Different figure means significant differences in the same week $(\mathrm{P}<0.05)$. Values are means \pm SEM for 12 ( 0 and $0.2 \%$ groups) and 10 birds (1.0\% group).

$1 \%$ red pepper. It is suggested that the sensitivity for the taste such as the irritant might be dull in the chicken.

Egg yolk color is one of important criteria for egg consumers and producers and is used to asscss the quality of eggs. To evaluate the egg yolk color, many methods have been developed. In the present study, we have applied two methods; one was the most common method, Roche color fan score, and the other was the use of the chroma meter. To compare the value obtained by two methods, it was clear that Roche color fan score was increased depending upon the redness of egg yolk color. Because the red pigment in the red pepper is capsanthin, the relationship between Roche color fan score and capsanthin (X, mg/kg diet) was calculated as follows,

Roche color fan score $=9.19+0.784 \mathrm{X}$.

This equation means that $1 \mathrm{mg}$ of capsanthin enhances 0.784 as Roche color fan score. 
In turn, $1.28 \mathrm{mg}$ capsanthin $/ \mathrm{kg}$ diet is necessary to increase one score of Roche color fan score.

\section{References}

DalRymple, R.H. and D.L. INGLE (1987) Effect of the beta-agonist cimaterol on growth, food efficiency and carcass composition in poultry in the U.S.A. In 'Beta-agonists and their effects on animal growth and carcass quality (HANRAHAN, J.P., ed.)', pp. 163-172. Elsevier Applied Science, London.

DunCAN, D.B. (1955) Multiple range and multiple F test. Biometrics 11 : 1-42.

Furuse, M., S. Nakajima, J. Nakagawa, T. Shimizu and J. Oкumura (1990) Regulation of lipid metabolism by dietary sorbose in laying hens. Poultry Science, $69: 1508-1512$.

HoRI, T. (1984) Capsaicin and central control of thermoregulation. Pharmacology and Therapeutics, $26: 389-416$.

JANCSO, G., E. KIRALY and A. JANCSO-GABOR (1977) Pharmacologically-induced selective degeneration of chemosensitive primary sensory neurons. Nature, 270:741-743.

JESSELL, T.M., L.L. IverSen and A.C. Cuello (1978) Capsaicin-induced depletion of substance P from primary sensory neurons. Brain Research, 152: 183-188.

KaWADA, T., K.-I. HagiHARA and K. Iw AI (1986a) Effects of capsaicin on lipid metabolism in rats fed a high fat diet. Journal of Nutrition, 116:1272-1278.

Kawada, T., T. Watanabe, T. Takaishi, T. Tanaka and K. Iwai (1986 b) Capsaicin-induced $\beta$-adrenergic action on energy metabolism in rats : influence of capsaicin on oxygen consumption, the respiratory quotient, and substrate utilization. Proceeding of the Society for Experimental Biology and Medicine, 183 : 250-256.

Muramatsu, T., M. Kakita, Y. Aoy agi and J. OKumura (1991) $\beta$-adrenergic agonist effects on liver and breast muscle protein synthesis in female chicks. Poultry Science, $70: 1630-1632$.

NAGY, J. L., S.P. HUNT, L.L. IVERSEN and P.C. EMSON (1981) Biochemical and anatomical observations on the degeneration of peptide-containing primary afferent neurons after neonatal capsaicin. Neuroscience, 6 : 1923-1934.

Pearson, A.W. and E.J. Butler (1978) The oestrogenised chick as an experimental model for fatty liver-haemorrhagic syndrome in the fowl. Research in Veterinary Science, 24:82-86.

SAS. (1985) SAS User's Guide : Statistics. SAS Inst. Inc., Cary, NC.

WOLFORD, J.H. and D. Polin (1972) Lipid accumulation and hemorrhage in livers of laying chickens. A study on fatty liver-hemorrhagic syndrome (FLHS). Poultry Science, 51 : 1707-1713. 


\title{
飼料唐辛子が産卵鷂の摄食行動, 腹腔脂肪含量及び 産卵成績に及ぼす影響
}

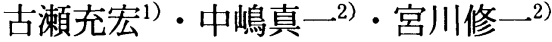 \\ 中川二郎 ${ }^{2)} \cdot$ 奥村純市 $^{1)}$ \\ 1)名古屋大学農学部, 名古屋市千種区不老町 464-01 \\ 2)豊橋飼料, 豊橋市 440
}

唐辛子の辛み成分として知られるカプサイシンには, $\beta$-アドレナリン作用があることが知られている。その作 用によりラットでは, 脂肪蓄積の低下及びエネルギー代 謝の高進が起こる。そこで本実験においては, 飼料唐辛 子が産卵鶏の攝食行動, 腹腔脂肪含量及び産卵成績によ゙ のような影響を及ぼすかを調查した。

産卵鶏用飼料にカプサイシンを $0.22 \%$ 含有する唐辛 子を $0,0.2$ 及び $1 \%$ となるように配合し，10 週間給与し た。その結果, 摂食行動に関しては, 短期的ならびに長 期的のどちらにおいても唐辛子による影響は認められな かった。産卵鶏は辛み成分に対し, 味覚があまり発達し ていないことが示唆された。

腹腔脂肪含量ならびに肝蔵脂肪含量は, 飼料唐辛子に
よりあまり影響を受けず，カプサイシンによる $\beta$ ーアド レナリン作用はニワトリにおいてはラットより屯小さい ものと推定された。また産卵成績は飼料唐辛子によりほ とんど影響を受けなかった。

卵黄色に関しては, 唐辛子含量の増加に伴いロッシュ のカラーファンスコアーと赤色度は増加するが, 黄色度 と明度は逆に低下した。

以上のことより，唐辛子は卵黄の着色剂としては有効 であるが，脂質の制御の点からすれば有効な飼料成分に なり得ないことが判明した。

（家禽会誌，31：45-52, 1994） キーワード : 唐辛子, カプサイシン, 産卵鶏, 腹腔脂肪, 卵黄色, カプサンチン 